\title{
Silage review: Foodborne pathogens in silage and their mitigation by silage additives ${ }^{1}$
}

\author{
O. C. M. Queiroz, ${ }^{*}$ I. M. Ogunade,† Z. Weinberg,ł and A. T. Adesogan $\S^{2}$ \\ *Animal Health and Nutrition, Ch. Hansen, Buenos Aires, 1107, Argentina \\ †Division of Food and Animal Science, College of Agriculture, Food Science and Sustainable Systems, Kentucky State University, \\ Frankfort 40601 \\ $\ddagger$ Department of Food Science, Agricultural Research Organization, the Volcani Center, Bet Dagan, 50250, Israel \\ $\S$ Department of Animal Sciences, Institute of Food and Agricultural Science, University of Florida, Gainesville 32606
}

\section{ABSTRACT}

Silage is one of the main ingredients in dairy cattle diets and it is an important source of nutrients, particularly energy and digestible fiber. Unlike properly made and managed silage, poorly made or contaminated silage can also be a source of pathogenic bacteria that may decrease dairy cow performance, reduce the safety and quality dairy products, and compromise animal and human health. Some of the pathogenic bacteria that are frequently or occasionally associated with silage are enterobacteria, Listeria, Bacillus spp., Clostridium spp., and Salmonella. The symptoms caused by these bacteria in dairy cows vary from mild diarrhea and reduced feed intake by Clostridium spp. to death and abortion by Listeria. Contamination of food products with pathogenic bacteria can cause losses of millions of dollars due to recalls of unsafe foods and decreases in the shelf life of dairy products. The presence of pathogenic bacteria in silage is usually due to contamination or poor management during the fermentation, aerobic exposure, or feed-out stages. Silage additives and inoculants can improve the safety of silage as well as the fermentation, nutrient recovery, quality, and shelf life. This review summarizes the literature on the main foodborne pathogens that occasionally infest silage and how additives can improve silage safety.

Key words: silage, pathogen, food safety, milk

\section{INTRODUCTION}

Silages are among the most common dietary ingredients used on modern dairy and beef operations but silage quality is often measured without assessment of the presence of pathogenic microorganisms and toxins.

Received September 26, 2017.

Accepted November 27, 2017

${ }^{1}$ This article is part of a special issue on silage management.

${ }^{2}$ Corresponding author: adesogan@ufl.edu
Yet poorly made or contaminated silages can harbor pathogens (Nightingale et al., 2004; Vilar et al., 2007) that reduce animal performance (Driehuis, 2013), cause diseases of cattle (Pedroso et al., 2010), and constitute a threat to human health (Ogunade et al., 2016; Driehuis et al., 2018).

Forages are typically contaminated with pathogens when slurry is spread on the fields as a fertilizer or when forages are contaminated with soil-borne pathogens during harvest (Davies et al., 1996; Russell et al., 2000). Cattle are the main reservoir of certain pathogenic microorganisms such as Escherichia coli O157:H7 (Chapman et al., 1997; Mechie et al., 1997), which can enter slurry lagoons via cattle manure and subsequently be irrigated on crops. Consequently, silage, like other livestock feeds, can be an important vehicle of transmission of pathogens on the farm (Lynn et al., 1998; Pedroso et al., 2010). Inadequate silage fermentation and poor silage feed-out management favor the proliferation of pathogens in silage (Pedroso et al., 2010). The most common pathogenic microorganisms that are found in silage are Escherichia coli, particularly E. coli O157:H7, Listeria monocytogenes, Bacillus spp., Salmonella, and Clostridium spp. (Wilkinson, 1999).

Silage bacterial inoculants and chemical additives are known for their positive effects including improving fermentation, increasing DM and nutrient recovery, and extending aerobic stability. In addition to these effects, some commercial additives have demonstrated the capacity to mitigate the pathogenicity of silage, and thereby preventing the spread of pathogens on the farm. The objective of the current review is to summarize the literature on the main foodborne pathogens in silage and their mitigation by the use of silage additives or inoculants.

\section{ENTEROBACTERIA}

Enterobacteria are gram-negative facultative anaerobic bacteria. Some species of enterobacteria can 
use nitrate as an electron aceptor in place of oxygen (Muck, 2010). Epiphytic enterobacteria, including Erwinia herbicola and Rahnella aquitilis, often dominate fresh crops, but others supersede these during ensiling such as Escherichia coli, Hafnia alvei, and Serratia fonticola (Driehuis and Elferink, 2000). Enterobacteria deaminate and decarboxylate AA in silages and reduce $\mathrm{NO}_{3}$, thereby enhancing ammonia and biogenic amine production (Pahlow et al., 2003). Enterobacteria also compete with lactic acid bacteria (LAB) for nutrients during fermentation (Pahlow et al., 2003); however, their growth and viability decrease as the $\mathrm{pH}$ declines (Heron et al., 1993). Factors that impair silage fermentation or contamination of aerobically exposed silage can provide conducive conditions for growth of these bacteria (Ogunade et al., 2017).

Escherichia coli O157:H7, a Shiga toxin producing gram-negative bacterium, is the most notorious of the enterobacteria. It is a foodborne pathogen associated with hemorrhagic colitis and hemolytic uremic syndrome, a severe illness characterized by anemia and kidney failure in children and the elderly (USDAAPHIS, 2001). The main source of milk contamination is undoubtedly fecal (Hussein and Sakuma, 2005; Farrokh et al., 2013) though an intramammary source due to pre- or subclinical mastitis is possible (Stephan and Kuhn, 1999), though controversial (Farrokh et al., 2013). Cattle are the main reservoir of E. coli O157:H7 and more than $30 \%$ of all cattle are asymptomatic carriers (Callaway et al., 2006; Reinstein et al., 2007). Forage and silage can be contaminated with E. coli O157:H7 via manure or irrigation water (Weinberg et al., 2004), and the pathogen has been commonly detected as part of the epiphytic microbial population of some forage crops (Driehuis, 2013; Ogunade et al., 2016). A rapid drop in $\mathrm{pH}$ has been shown to eliminate E. coli in silage (Bach et al., 2002; Byrne et al., 2002). Pedroso et al. (2010) evaluated the effectiveness of 3 commercial bacterial inoculants at controlling E. coli O157:H7 in corn silages. The pathogen was eliminated within $3 \mathrm{~d}$ of ensiling with or without silage inoculation when the $\mathrm{pH}$ dropped below 4.0. In a similar study, $E$. coli $\mathrm{O} 157: \mathrm{H} 7$ was eliminated from ensiled, artificially contaminated wheat and corn forages when the $\mathrm{pH}$ dropped below 5.0 (Chen et al., 2005). A similar result was observed for E. coli O26, a different pathogenic strain of E. coli, in corn silages (Duniere et al., 2011). The elimination of this pathogen in these studies was probably due to the inhibitory low $\mathrm{pH}$, the enhanced antimicrobial activities of organic acids at low $\mathrm{pH}$, or both (Bjornsdottir et al., 2006).

Pathogenic E. coli may persist during ensiling when the acidification rate is low (Weinberg et al., 2004; Ogunade et al., 2017). Chen et al. (2005) used an E. coli strain that was tagged with a green fluorescent protein and was resistant to kanamycin to inoculate wheat and corn forages, and reported that the strain survived longer in wilted wheat silages because the $\mathrm{pH}$ decreased more slowly than in direct-cut unwilted silages. Ogunade et al. (2016) demonstrated that compared with untreated samples, inoculation of alfalfa with Lactobacillus plantarum or L. buchneri increased the rate of $\mathrm{pH}$ decline, which led to earlier inhibition $(7$ vs. $16 \mathrm{~d})$ and eventually elimination of $E$. coli O157:H7, which was added at ensiling. The slow rate of $\mathrm{pH}$ decline in the control alfalfa silage was attributed to the high buffering capacity, the low water-soluble carbohydrate concentration, or both. In a similar trial using corn silage, which has much lower buffering capacity than alfalfa, within $3 \mathrm{~d}$ of fermentation the $\mathrm{pH}$ had decreased below 4.0 and the pathogen had been eliminated from silages that were or were not inoculated with L. plantarum or L. buchneri (Ogunade et al., 2017). However, when all silages were subsequently reinoculated with $E$. coli after aerobic exposure, the $L$. plantarum and control silages had higher $E$. coli counts (5.39 and $5.30 \log \mathrm{cfu} / \mathrm{g}$, respectively) and higher $\mathrm{pH}$ values (5.67 and 6.13, respectively) compared with the L. buchneri silages, which had a $\mathrm{pH}$ value of 4.24 and an approximately 10,000-fold lower E. coli count.

Most of the experiments that studied the survival of pathogenic E. coli used laboratory silos, which are more controlled environments than farm silos. Farm silos are more prone to air penetration and soil contamination (Jonsson et al., 1990), which can enhance the growth of undesirable microbes. For instance, the presence of oxygen in the silo prolonged the survival of pathogenic E. coli during ensiling (Duniere et al., 2011; Driehuis, 2013). Under aerobic conditions that prevail after ensiling, factors that reduce silage acidity can increase the E. coli population (Donald et al., 1995). Substantial (up to $4,000 \mathrm{cfu} / \mathrm{g}$ of silage) E. coli populations were found in the upper corners or shoulders of commercial wheat and corn silages stored in aerobically exposed bunker silos (Weinberg et al., 2004) during the feed-out stage. The high population densities in these areas are due to the low density of the silage in the shoulders, which makes them more prone to air penetration with subsequent increased $\mathrm{pH}$ values and spoilage (Weinberg et al., 2004).

Pedroso et al. (2010) monitored the survival of $E$. coli $\mathrm{O} 157: \mathrm{H} 7$ in aerobically exposed corn silage samples experimentally inoculated with the pathogen after silo opening to mimic survival of the ensiling process by the pathogen, postensiling contamination, or both. The control silage or those treated with $E$. coli alone, or E. coli and a mixture of P. pentosaceus and P. freudenreichii, had high $\mathrm{pH}$ values $(4.71,5.67$, and 6.09) 
and high counts of the pathogen $(2.87,6.73$, and 6.87 $\mathrm{cfu} / \mathrm{g})$, whereas those treated with $L$. buchneri alone or with L. buchneri and P. pentosaceus had lower $\mathrm{pH}$ values $(<4)$ and low or no $E$. coli counts, respectively. This study showed that to prevent the growth of $E$. coli in silage, it is critical to maintain the $\mathrm{pH}$ below 4 during and after ensiling. This can only be achieved by good management practices such as an adequate feed-out rate as well as use of appropriate silage additives that increase the acidification rate during ensiling and prevent growth of lactate-utilizing yeasts, which increase the silage $\mathrm{pH}$ during the feed-out stage.

In addition to $\mathrm{pH}$-mediated inhibition, bacterial metabolites may also directly inhibit the growth of pathogens. Pure cultures of L. buchneri and L. plantarum have exhibited $\mathrm{pH}$-independent antibacterial activity against E. coli O157:H7 (Pedroso et al., 2010; Ogunade et al., 2017). Similar results on Micrococcus luteus and Pseudomonas aeruginosa were observed by Gollop et al. (2005) who studied the antibacterial effects of 10 silage inoculants (3 strains of L. plantarum, 2 strains of $P$. pentosaceus, 1 strain of $L$. pentosus, 3 strains of E. faecium, and 2 strains of L. buchneri). However, the specific antibacterial compounds that inhibited the growth of the pathogens were not identified in these studies. Some studies have shown that LAB including those used in silage inoculants such as L. lactis, $L$. plantarum, and L. buchneri can produce bacteriocins (Yildirim et al., 2002; Field et al., 2012). These antimicrobial peptides can eliminate or reduce the growth of other bacteria related to the strain producing them (Yang et al., 2014). Lactococcus lactis, for example, is a nisin-producing bacteria that has reduced butyrate and ammonia production by Clostridium spp. (Jatkauskas et al., 2015), but the relative contribution of nisin to the reduction is unknown. In fact, to our knowledge, no silage inoculants rely primarily on bacteriocin activity for their beneficial effects on silage quality and preservation.

Lactobacillus species have been used commercially, as an orally ingested probiotic, to reduce pathogenic $E$. coli shedding in feedlot operations in the United States. A direct-fed microbial (DFM) combination of L. acidophilus (LA51) and P. freudenreichii (NP24) reduced the prevalence of $E$. coli shedding by finishing steers and also improved their feed efficiency by approximately 2\% (Elam et al., 2003). Peterson et al. (2007) evaluated the effect of supplementing L. acidophilus NP51 on the performance and reduction of $E$. coli shedding by finishing steers in a 2-yr study. No treatment effect was found on daily gain (1.67 vs. $1.69 \mathrm{~kg} / \mathrm{d})$, feed efficiency (0.147 vs. 0.150$)$, or DMI (11.42 vs. $11.31 \mathrm{~kg} / \mathrm{d}$ ). However, DFM-treated steers were $35 \%$ less likely to shed E. coli O157:H7 than those fed the control diet.
Due to the high cost of vaccinating ruminants to reduce shedding of pathogenic E. coli (Lueger et al., 2012), and the potential benefits of Lactobacillus-based DFM products (Lema et al., 2001; Brashears and Galyean, 2002), future studies should evaluate the effects of other Lactobacillus-based silage inoculants on fecal shedding of pathogenic E. coli.

\section{LISTERIA}

Listeria are opportunistic gram-positive facultative anaerobic bacteria that cause high mortality and a wide range of diseases in immune-compromised animals and humans including meningitis, encephalitis, septicemia, gastroenteritis, mastitis, and late-term abortions (McDonald et al., 1991; Wesley, 2007). It is estimated that in the United States annually, clinical cases of listeriosis can be as many as 2,500 and up to 500 deaths can result (Mead et al., 1999). Whereas the fatality rate in humans is around 20\%, that of livestock can be as high as $100 \%$ (Schukken et al., 2003). Listeria monocytogenes (formerly Bacterium monocytogenes) is the main causative agent, and spoiled silage is considered to be the main source of this pathogen in ruminants (Wiedmann, 2003). This pathogen is ubiquitous and seems to be more prevalent in dairy operations (Nightingale et al., 2004, 2005; Ho et al., 2007a,b). The capacity of $L$. monocytogenes to survive in different environments and hosts is unique to non-spore-forming bacteria and is related to the fact that it can tolerate refrigeration temperatures, low water activity, and a wide range of $\mathrm{pH}$. Previous studies indicated that the organism requires pH values above 5 (McDonald et al., 1991), but Ryser and Marth (2007) reported that some strains survived $\mathrm{pH}$ values below 4.0. The presence of $L$. monocytogenes in silages is frequently associated with poor fermentation. Vilar et al. (2007) conducted a cross-sectional study on the prevalence and source of L. monocytogenes in milk from 98 dairies in Spain and statistically verified the relationship between presence of Listeria spp. in silage and low silage quality as indicated by a high $\mathrm{pH}$. Silages samples with $\mathrm{pH}$ equal to or above 4.5 had more samples that had L. monocytogenes than silages with lower $\mathrm{pH}$ ( 29.5 vs. $6.2 \%$, respectively).

The pathogen thrives in parts of the silage where oxygen is not properly excluded or in others exposed to oxygen infiltration, because they are inhibited by low $\mathrm{pH}$ conditions. However, those that survive ensiling may experience a growth surge if the $\mathrm{pH}$ increases beyond 4.5 after silo opening. The pathogen is commonly found in baled silages because of their relatively low density, high $\mathrm{pH}$, high surface area to mass ratio, and presence of aerobic pockets due to plastic damage or insufficient number of plastic layers in baled silage (McDonald et 
al., 1991; Nucera et al., 2016). In Britain, outbreaks of listeriosis are more commonly associated with sheep because cattle are more resistant and sheep are more commonly fed baled silages (McDonald et al., 1991). Nevertheless, cattle are often asymptomatic carriers of the pathogen (Vilar et al., 2007).

Listeria monocytogenes can be transmitted from contaminated silages into milk. Fortunately, the pathogen is destroyed by adequate pasteurization but may survive in soft cheeses and dairy products that are not subjected to such treatments (Griffiths, 1989). Most of the research on the presence of Listeria in silages has focused on the fermentation characteristics of the silage. Pauly and Tham (2003) found high correlations between silage $\mathrm{pH}(\mathrm{r}=0.92)$, the concentration of lactic acid $(\mathrm{r}=-0.80)$, and the pooled amount of undissociated acids $(\mathrm{r}=-0.83)$ with the presence of Listeria monocytogenes in grass silage. The authors also demonstrated that ensiling wilted silages with high DM content $(540 \mathrm{~g} / \mathrm{kg})$ did not reduce Listeria counts, indicating that low moisture conditions did not inhibit the pathogen. In the same experiment, L. plantarum inoculation reduced the Listeria population in direct cut $(200 \mathrm{~g} / \mathrm{kg}$ of DM) and wilted grass silage $(430 \mathrm{~g} / \mathrm{kg}$ of DM) by 2.2 and $7.9 \mathrm{log}$ cfu/g. Wilson et al. (2005) confirmed the anti-listerial activity of lactic acid by using cell-free culture filtrates of MRS broth to grow a specific strain of L. plantarum SK1. They demonstrated that lactic acid alone reduced Listeria counts by $3.0 \mathrm{log}$ $\mathrm{cfu} / \mathrm{mL}$ of de Man, Rogosa, and Sharpe broth during the late log or early stationary phase of growth.

Bacteriocins also have been identified as agents that control Listeria. Mantovani and Russell (2003) demonstrated that bovicin HC5, a bacteriocin produced by Streptococcus bovis HC5, which causes efflux of intracellular potassium at $\mathrm{pH}$ below 6.0 , has a bactericidal effect on $L$. monocytogenes and is capable of decreasing viability by 5 to $7 \operatorname{logs}$ after $2 \mathrm{~h}$ of exposure. Acidadapted L. monocytogenes ( $\mathrm{pH} 4.6$ ) was as sensitive to bovicin as non-acid-adapted cells. Sparo et al. (2006) characterized enterocin MR99, a bacteriocin produced by Enterococcus faecalis isolated from early-fermented corn silage (less than $15 \mathrm{~d}$ ), and showed that the protein is stable over a wide range of $\mathrm{pH}(4.0-8.0)$ and heat resistant with proven bactericidal effect on Listeria. Amado et al. (2012) used pour plating to show that a combination of nisin-producing Lactococcus lactis CECT 539 and pediocin-producing Pediococcus acidilactici NRRL B-5627 with L. plantarum prevented survival of $L$. monocytogenes in corn and ryegrass silages within $24 \mathrm{~h}$ of fermentation. The authors also used the PCR-degrading gradient gel electrophoresis (DGGE) technique to determine if L. monocytogenes had become viable but not culturable during the fer- mentation. The DGGE profiles revealed the DNA band for the pathogen disappeared after $16 \mathrm{~d}$ of fermentation in untreated ryegrass silages, but it had disappeared within $2 \mathrm{~d}$ in inoculated silages. In the same trial, when L. plantarum was applied to ryegrass in combination with either L. lactis or P. acidilactici, the DNA band for the pathogen disappeared after $5 \mathrm{~d}$ of fermentation, which indicates a synergistic inhibitory effect when both bacteriocin-producing bacteria were inoculated with L. plantarum. This synergistic effect is partly attributable to the low $\mathrm{pH}$ achieved $(<4.0)$ within $2 \mathrm{~d}$ of fermentation when the combination inoculant was used. Low $\mathrm{pH}$ values promote the release of nisin and pediocin from cell surfaces of L. lactis and P. acidilactici, respectively (Guerra at al., 2001), and at pH of 3.5, both bacteriocins exhibit their maximum antibacterial activity (Guerra and Pastrana, 2002).

Amado et al. (2016) evaluated the effect on L. monocytogenes in corn silage of pediocin alone or combined with an inoculant containing a mixture of L. plantarum, E. faecium, and L. buchneri $\left(1 \times 10^{6} \mathrm{cfu} / \mathrm{g}\right)$. The DGGE profiles of the PCR products targeting the iap gene of L. monocytogenes disappeared within $8 \mathrm{~d}$ in silages treated with pediocin with or without the inoculant, but that for the untreated silage persisted until the last silo opening time on d 30 of fermentation. These results confirm that bacteriocins or bacteriocinproducing bacteria can be effective additives to control Listeria in silages. Follow-up studies are needed to ensure that these additives decrease shedding of Listeria by dairy or beef cattle and have no negative effects on their health and performance.

\section{BACILLI}

Bacillus spp. are gram-positive, aerobic or facultative anaerobic, sporulating bacteria, and their endospores are able to tolerate harsh environmental temperatures, including milk pasteurization or boiling temperatures (Pahlow et al., 2003; Masiello et al., 2014). Bacillus spp. and other aerobic, less acid-tolerant microorganisms, such as molds and Listeria, usually grow in the silage after the oxidation of lactic acid by yeast under aerobic conditions (te Giffel et al., 2002; Vissers et al., 2007a). Therefore, preventing aerobic spoilage of silage can reduce the risk of silage contamination with Bacillus spp. However, Bacillus spp. may initiate spoilage in certain instances such as under high temperatures, in big bale silages, or after treatment with formaldehyde or antibiotics (McDonald et al., 1991). Though no supporting studies were found, it is likely that more Bacillus spores will be present on outer layers of bales than in central, tightly packed layers due to the greater exposure to oxygen of the former. Warm summer condi- 
tions also favor the increase of spore counts of thermoduric Bacillus spp. in corn silage and bulk tank milk samples. Buehner et al. (2014) reported that the spore counts in corn silage samples increased from $3.60 \mathrm{log}$ in winter to $6.33 \mathrm{log}$ during summer, and spore counts in milk samples also doubled.

Contamination of milk with Bacillus spores is often due to soil contamination with the pathogen, but in many cases the diet is the inoculum. Bacillus cereus is particularly notorious because, when ingested, its spores can pass through the digestive tract intact, contaminate the milk of dairy cows, survive pasteurization temperatures, and decrease the shelf life of milk and cream (Christiansson et al., 1999; Pahlow et al., 2003). Furthermore, enterotoxins produced by these bacteria cause foodborne illnesses, notably emesis and diarrhea (Bennett et al., 2013). A positive relationship between the number of spores in the feces and milk $(\mathrm{r}=0.78, P$ $<0.001$ ) was observed when cows were fed increasing doses of B. cereus spores (Magnusson et al., 2007). The authors suggested that there was an elevated risk of having increased spore levels in milk $(>100 / \mathrm{L})$ if the spore content in the feces exceeded 10,000 to 100,000 spores/g. That level of shedding was obtained when cows were fed $9 \times 10^{8}$ to $9 \times 10^{9}$ spores of $B$. cereus $/ \mathrm{d}$.

Mitigation strategies to reduce Bacillus spp. contamination in silage should aim to control aerobic and facultative anaerobic bacteria that are not necessarily suppressed by fermentation products or low $\mathrm{pH}$ (Woolford, 1975; Pahlow et al., 2003). Under proper ensiling conditions, Bacillus spp. should not be able to compete for carbohydrates with LAB or cause significant changes in total acid concentration or $\mathrm{pH}$ (Moran et al., 1993). Homofermentative LAB inoculants could be used to dominate Bacillus spp. and other undesirable bacteria and promote an efficient homolactic fermentation. Aerobic Bacillus spp. are more prone to develop on the surface and side walls of silos due to oxygen penetration and low silage density, respectively. However $B$. cereus occurs in silage, it does not increase in numbers to the same extent as other Bacillus spp. or aerobic spore-formers (Driehuis, 2013). Vissers et al. (2007b) quantified B. cereus spores in feed, feces, bedding, and raw milk on Dutch farms and concluded that the population of $B$. cereus (maximum $4.0 \log _{10}$ ) in silage samples was not critical for milk contamination. Nevertheless, the number of $B$. cereus spores can vary in silages; thus, it should always be considered as a possible source of contamination.

Sorbate and benzoate are effective preservatives to minimize the growth of Bacillus spp. (Woolford, 1975). Thomas et al. (1993) used a gradient gel plate technique to study the effect of preservatives (sodium benzoate, sodium nitrite, and potassium sorbate), $\mathrm{pH}$, tempera- ture, and sodium chloride concentration on the growth of B. cereus, E. coli, and S. aureus. Potassium sorbate was the most effective preservative to control $B$. cereus at $\mathrm{pH}$ 6.7. The higher effectiveness of sorbate versus benzoate is mainly because the undissociated form has the antimicrobial effect and the pKa of sorbate is higher (4.75) than that of benzoate (4.2; Kung et al., 2003).

Most of the foodborne pathogen mitigation methods used in the food industry are inadequate to treat silage because they are based on factors that cannot be applied to large silage quantities in farm-scale silos. These include application of heat $\left(75^{\circ} \mathrm{C}\right.$ to kill vegetative cells and $121^{\circ} \mathrm{C}$ to inactivate Bacillus spores), UV radiation, high pressure, and pulsed electric fields (Soni et al., 2016). However, nisin is promising for controlling Bacillus spores in contaminated food (Kuwano et al., 2005: Bermudez-Aguirre et al., 2012). Nisin may also have a role in controlling Bacillus spores in silage because nisin-producing bacteria have decreased silage contamination with other pathogenic bacteria such as L. monocytogenes (Amado et al., 2016). Future research should examine the potential of bacteriocins and bacteriocin-producing silage inoculants to inhibit the growth of Bacillus spp. in silage.

\section{CLOSTRIDIA}

Clostridium spp. are gram-positive, mostly obligate anaerobic, sporulating bacteria that thrive in low-sugar silages particularly when plant moisture $(>70 \%), \mathrm{pH}$ $(>4.6)$, temperature $\left(>30^{\circ} \mathrm{C}\right)$, and buffering capacity are high. Consequently, they often dominate the fermentation of unwilted legumes ensiled without additives (McDonald and Whittenbury, 1973) and can also be common in unwilted tropical grass silages (Adesogan et al., 2004). The presence of Clostridium spp. in silage is mainly from soil contamination or slurry application and this can lead to contamination of animal feeds and products. The outer layer of baled silos and top layer of bunker silos are usually more prone to clostridial spore formation. For instance, Borreani et al. (2013) reported that the central part of a corn silage bunker silo had less than $10^{3}$ spores of Clostridium spp. per gram of silage, whereas the peripheral area had more than $10^{6}$ spores per gram. Spores present in the feed can survive digestion and get into manure or dirt from which they get onto the exterior of teats and contaminate milk (Vissers et al., 2007b). Clostridium spp. most commonly found in silage include saccharolytic types that ferment several sugars (e.g., C. butyricum), few sugars and lactic acid (e.g., C. tyrobutyricum), and others that ferment both sugars and AA (e.g., C. sporogenes and C. perfringens); however, those that ferment AA exclusively are uncommon in silages (Pahlow et al., 2003). 
Certain saccharolytic Clostridium spp. derive energy for growth by fermenting sugars and lactate into butyric acid, $\mathrm{CO}_{2}$, and $\mathrm{H}_{2}$. Although the antifungal properties of butyric acid can enhance aerobic stability (Adesogan et al., 2004), its presence in silages can increase problems with ketosis within the herd (Andersson and Lundstrom, 1985).

Depletion of lactate at feed-out by yeast and saccharolytic Clostridium spp. in silage increases the $\mathrm{pH}$, leading to increased growth of proteolytic Clostridium spp. that deaminate and catabolize AA into fatty acids (McDonald et al., 1991). Consequent increases in the ammonia concentration and protein solubility make silage protein less ideal for high-producing cattle and enhance nitrogen pollution from cows fed such silages. Furthermore, biogenic amines such as cadaverine, glucosamine, histamine, putrescine, and tyramine can be produced during clostridial proteolysis in silages. Although they are present in small quantities in all cells and can be ruminally degraded to a large extent (Van Os et al., 1995; Phuntsok et al., 1998), biogenic amines are potentially toxic. Many of these putrefaction-associated compounds are malodorous and unpalatable; therefore, they reduce feed intake by livestock. Fusi et al. (2004) showed that oral administration of biogenic amines to kids reduced DMI, growth rate, and BW and adversely affected histological characteristics and carcass quality. Furthermore, histamine is lethal at high doses, and when injected intravenously at low doses, it stopped ruminal motility and eructation (Dain et al., 1955). Intake of putrescine has also been associated with ketonemia and depressed milk production in cattle (Lingaas and Tveit, 1992).

Although Clostridium spp. are normal flora of ruminant digestive tracts, dietary stress, injury, management changes, and parasitism can make them produce potent toxins that cause sudden bouts of abdominal pain, diarrhea, ulceration, and even death in calves (McGuirk, 2008). Enteric syndromes in cows, humans, lambs, and monogastric livestock are also common. Clostridium perfringens type $\mathrm{A}$ is frequently found in most cows with hemorrhagic bowel syndrome, consequently it is thought to be involved in the etiology of the syndrome. Rings (2004) cited studies in which outbreaks of botulism B in cattle were reported after wrapped smallgrain haylages and ryegrass silage were fed and noted that $C$. botulinum grows and produces the neurotoxin when silage fermentation fails to achieve a $\mathrm{pH}$ less than 5.3. However, occurrence of C. botulinum in silages is rare (Driehuis and Elferink, 2000). An added clostridial problem is that spores transmitted from silage into milk can form outgrowths or gas pockets that double the size of cheese due to butyric fermentation. The resulting phenomenon, late blowing of cheese, and the large quantities of butyric acid produced by clostridial fermentation result in a rancid odor and tainted flavor of cheese (Cocolin et al., 2004).

Clostridium spp. are known to be intolerant of low (4.5) pH (Kaiser and Weiss, 1997; Kaiser et al., 1997); therefore, any additive, such as homofermentative bacteria, that can increase lactate concentration and hasten the $\mathrm{pH}$ drop during fermentation should inhibit clostridial activity in silage. When crops low in clostridia-inhibiting nitrates, such as grasses and immature whole crop cereals, are ensiled, LAB additives that ensure rapid acidification can reduce clostridial spores in the silage (Pahlow et al., 2003). The minimum number of epiphytic or added LAB (or both) required to inhibit clostridial growth is at least $100,000 \mathrm{cfu} / \mathrm{g}$ on a fresh weight basis (Weissbach and Honig, 1996; Kaiser et al., 1997). In contrast, silage additives that reduce acidification and increase the $\mathrm{pH}$ can lead to a clostridial fermentation. Custódio et al. (2016) reported that treating sugarcane silage with $15 \mathrm{~g} / \mathrm{kg}$ of lime resulted in higher $\mathrm{pH}$ (3.62 vs. 4.8) and higher Clostridium spp. count (3.3 vs. $6.7 \mathrm{log} \mathrm{cfu} / \mathrm{g}$ ) than the untreated silage. Various doses of sodium nitrite $(0,0.5$, 1.0 , or $1.5 \mathrm{~g} / \mathrm{kg}$ as fed) did not reduce the clostridial growth in the lime-treated silage.

Wilting also depresses clostridial growth (van Schooten et al., 1989) because of the affinity of Clostridium spp. for moisture. Clostridial spore counts decreased as DM content of grass at ensiling increased from 30 to 45\% (Hengeveld, 1983).

Chemical additives can also reduce clostridial spores in silage. Application of a mixture of sodium benzoate, sodium nitrite, hexamine, and sodium propionate inhibited clostridial growth in low-wilted forages (Lättemäe and Lingvall, 1996). Similar results were obtained by Jonsson et al. (1990). Combinations of sodium nitrite and hexamine have also been effective at inhibiting Clostridium spp. (Lättemäe and Lingvall, 1996) as well as nitrite alone (Spoelstra, 1985).

\section{SALMONELLA}

Salmonella are gram-negative, facultative aerobic, motile rods, and enteric bacteria (Madigan et al., 2009). Salmonella enterica is an important pathogen that causes about 42,363 cases of foodborne illness per annum in the United States (Scallan et al., 2011). Peaks in the number of salmonellosis outbreaks are frequently associated with intake of raw or improperly pasteurized milk. Salmonella enterica is relatively common on and is represented by diverse serotypes on dairy farms (Callaway et al., 2005). Common symptoms of salmonellosis in cattle are watery or bloody diarrhea, dehydration, fever, depression, and poor performance. 
A survey evaluating the prevalence of salmonella and other pathogenic bacteria in US dairies demonstrated that 22 out of 861 bulk tank milk samples were contaminated with 9 different types of Salmonella serotypes, including the Newport serotype, which is known to exhibit resistance to multiple antimicrobials (multidrug resistant; Van Kessel et al., 2004). An observational study in Washington State determined that the rate of new multidrug-resistant Salmonella strain introduction was 0.9 per herd-year (Adhikari et al.,2009), whereas in Wales and England a similar study reported an incidence rate of 0.43 cases of salmonellosis per farm-year for any serovar of Salmonella enterica (Davison et al., 2006). The transmission of Salmonella to herds seems to be more associated with management as the introduction is typically via contaminated animals, tools, and people, and less related to feed source (Langvad et al., 2006; Nielsen et al., 2007; Adhikari et al., 2009). In fact, Hanson et al. (2016) provide evidence of vertical transmission from a contaminated dam to her fetus such that dairy calves were born with the infection.

In the Washington State survey, from a total of 4,582 pooled feed samples from 59 herds and 665 samples from feed mills, only $3.5 \%$ were positive for Salmonella spp., including one corn silage sample that was positive for Salmonella typhimurium (Adhikari et al., 2009). The use of sewage water or slurry to irrigate fields dedicated to silage making is an important risk factor for silage contamination with Salmonella. Weinberg et al. (2004) evaluated fresh plant and silage samples of sewageirrigated sorghum and corn fields in Israel and found only 1 silage sample was positive for Salmonella out of 5 corn silage samples. The contaminated sample was from a field were the fresh plant samples were also positive for Salmonella. Natural disasters such as storms, hurricanes, flooding, hailstorms or lodging can cause soil sediment contamination of forages and increase epiphytic counts of Salmonella and other pathogens. Nevertheless, if the fermentation is well established and a low $\mathrm{pH}(<4)$ is achieved, pathogens that require high $\mathrm{pH}$ for growth such as Salmonella will not survive. Therefore, the appearance of the pathogen in silage reflects poor silage-making practices or contamination after ensiling.

Ensiling duration seems to be an important factor affecting the population of Salmonella, especially in silages with low rates of $\mathrm{pH}$ decline. Johansson et al. (2005) examined the presence of Salmonella in artificially contaminated $\left(1 \times 10^{8} \mathrm{cfu} / \mathrm{g}\right)$ ryegrass ensiled at 39 and $61 \%$ of $\mathrm{DM}$ for 0,7 , and $60 \mathrm{~d}$ of fermentation. All the 20 silage samples from d 0 and 7 , were positive for Salmonella, whereas only 1 out of 5 samples from the wetter silage was positive after $60 \mathrm{~d}$.
In general, the incidence of Salmonella contamination of silages samples is low and contamination is usually only a problem if the silage fermentation is inadequate. Consequently, no studies on inhibition of Salmonella by silage additives or inoculants were found. Nevertheless, studies on additive inhibition of the growth of Salmonella that contaminates aerobically exposed silages are needed to avoid entry of the pathogen into the food chain. Silage inoculants and organic acids such as propionic and acetic acid may be effective based on their use to control the pathogen in feed ingredients (Carrique-Mas et al., 2007; Jones, 2011).

\section{STRATEGIES FOR ENSURING THE HYGIENIC QUALITY OF SILAGE}

Preventing contamination of silage and animal products with pathogens requires the identification of critical control points (Hazard Analysis and Critical Control Points) that are related to contamination and replication of pathogenic silage organisms on the farm (Lynn et al., 1998). Silage contamination with pathogenic microorganisms can occur before, during, or after ensiling, and it is critical that adequate control measures are used at each of these stages to prevent contamination.

Before and during ensiling, management practices that favor rapid homolactic fermentations should be ensured because a rapid $\mathrm{pH}$ drop is critical to inhibiting Clostridium spp. and enterobacteria, which cause proteolysis and secondary butyric fermentation. Specific measures include

1. Choosing forages with a high water-soluble carbohydrate-to-buffering capacity ratio, where available hybrids resistant to fungi should be used.

2. Harvesting at appropriate moisture concentrations for ensiling and optimizing nutritive value and biomass yield.

3. Wilting in a way that prevents proteolysis but increases DM concentrations to about 35\% for grasses and $45 \%$ for legumes.

4. Chopping forages to lengths that facilitate compaction but retain the physical effectiveness of the fiber.

5. Unloading forages promptly into silos lined with appropriate plastic sheets.

6. Compacting forages to a density of about $240 \mathrm{~kg}$ of $\mathrm{DM} / \mathrm{m}^{3}$ in the silo.

7. Sealing the silo promptly with appropriate sheets and maintaining anaerobic conditions for 
the duration of ensiling by regularly sealing any holes that develop in the plastic cover.

8. Additives are not always necessary for good fermentation, but they are particularly useful for enhancing the fermentation of crops with high buffering capacities, low water-soluble carbohydrate concentrations, or high moisture concentrations. Additives containing molasses, nitrate, inorganic and formic acids, buffered acids, or least $10^{5} \mathrm{cfu} / \mathrm{g}$ of specific LAB (L. plantarum, Pediococcus acidilacti, P. pentosaceous, and Enterococcus faecium) have enhanced homolactic fermentation by inhibiting undesirable bacteria, or increasing the rate of acidification, or dominating the flora. However, various additive and management-related factors determine additive efficacy. Therefore, more detailed reviews on the subject, such as that of Kung et al. (2003) and Muck et al. (2018), should be consulted before choosing an additive. Additives have also had secondary benefits for instance, inoculation with L. casei has successfully reduced the biogenic amine concentration of different silages, but $L$. buchneri inoculation had inconsistent effects (Nishino et al., 2007).

Yeasts, molds, Listeria, and enterobacteria that survive anaerobic fermentation grow rapidly when the $\mathrm{pH}$ is elevated during aerobic spoilage. Therefore, management practices that ensure the aerobic stability of silages and prevent increases in $\mathrm{pH}$ at feed-out are critical. To ensure aerobic stability, the following steps should be implemented:

1. Silo design should minimize the size of the silo face as wider faces facilitate oxygen ingress.

2. Where appropriate, shavers should be used to ensure smooth silo faces to minimize the surface area exposed and reduce oxygen ingress into the silage.

3. Silages should be fed out at rates that minimize the length of time the face is exposed to the air; feed-out rates of 5 to $10 \mathrm{~cm} / \mathrm{d}$ from tower silos, 10 to $15 \mathrm{~cm} / \mathrm{d}$ from bunker silos, and 30 or more $\mathrm{cm} / \mathrm{d}$ from bag silos have been recommended in the United States, whereas in Israel rates of 20 to $30 \mathrm{~cm} / \mathrm{d}$ are recommended (Muck et al., 2003). Feed-out rates in tropical areas should be at least $30 \mathrm{~cm} / \mathrm{d}$ (Whitlow and Hagler, 2009) because warm humid conditions enhance the growth of spoilage organisms.

4. Silage aerobic stability can be enhanced with propionic, acetic, sorbic, and benzoic acid because of their antifungal nature. These compounds are also sold as mold inhibitors. Lactobacillus buchneri degrade lactate to acetate, which inhibits the growth of yeasts and molds, thereby improving aerobic stability (Driehuis et al., 1999). Consequently, L. buchneri inoculants have been successfully used to improve the aerobic stability of several forages. Pedroso et al. (2010) reported that L. buchneri inoculants enhanced the aerobic stability of corn silages by increasing acetate production to levels that inhibited yeasts and minimized or prevented the attendant increases in $\mathrm{pH}$. Therefore, these L. buchneri inoculants curtailed the growth of $E$. coli $\mathrm{O} 157: \mathrm{H} 7$ in silages contaminated with the pathogen after silo opening. All of these additives should be uniformly distributed in the silage for maximum efficacy.

5. Antioxidants such as vitamin E and selenium; mold inhibitors such as propionic, sorbic, acetic, and benzoic acids; and mycotoxin binding adsorbents have been successfully used to reduce the risk of mycotoxicoses and prevent the transmission of aflatoxins into milk (Diaz et al., 2004; Whitlow and Hagler, 2009). Lactobacillus buchneri inoculation has also prevented aflatoxin synthesis in silages produced from corn plants infested with high levels of Southern rust (Queiroz et al., 2012).

\section{REFERENCES}

Adesogan, A. T., N. Krueger, M. B. Salawu, D. B. Dean, and C. R. Staples. 2004. The influence of treatment with dual-purpose bacterial inoculants or soluble carbohydrates on the fermentation and aerobic stability of Bermuda grass. J. Dairy Sci. 87:3407-3416.

Adhikari, B., T. E. Besser, J. M. Gay, L. K. Fox, M. A. Davis, R. N. Cobbold, A. C. Berge, R. McClanahan, and D. D. Hancock. 2009. Introduction of new multidrug-resistant Salmonella enterica strains into commercial dairy herds. J. Dairy Sci. 92:4218-4228.

Amado, I. R., C. Fucinos, P. Fajardo, N. P. Guerra, and L. Pastrana. 2012. Evaluation of two bacteriocin-producing probiotic lactic acid bacteria as inoculants for controlling Listeria monocytogenes in grass and maize silages. Anim. Feed Sci. Technol. 175:137-149.

Amado, I. R., C. Fucinos, P. Fajardo, and L. Pastrana. 2016. Pediocin SA-1: A selective bacteriocin for controlling Listeria monocytogenes in maize silages. J. Dairy Sci. 99:8070-8080.

Andersson, L., and K. Lundstrom. 1985. Effect of feeding silage with high butyric acid content on ketone body formation and milk yield in postparturient dairy cows. Zentralbl. Veterinarmed. A 32:15-23.

Bach, S. J., T. A. McAllister, J. Baah, L. J. Yanke, D. M. Veira, V. P. J. Gannon, and R. A. Holley. 2002. Persistence of Escherichia coli O157:H7 in barley silage: effect of bacterial inoculants. J. Appl. Microbiol. 93:288-294.

Bennett, S. D., K. A. Walsh, and L. H. Gould. 2013. Foodborne disease outbreaks caused by Bacillus cereus, Clostridium perfringens, and Staphylococcus aureus - United States, 1998-2008. Clin. Infect. Dis. 57:425-433.

Bermudez-Aguirre, D., C. P. Dunne, and G. V. Barbosa-C'anovas. 2012. Effect of processing parameters on inactivation of Bacillus cereus spores in milk using pulsed electric fields. Int. Dairy J. 24:13-21. 
Bjornsdottir, K., F. Breidt Jr., and R. F. McFeeters. 2006. Protective effects of organic acids on survival of Escherichia coli O157:H7 in acidic environments. Appl. Environ. Microbiol. 72:660-664.

Borreani, G., P. Dolci, E. Tobacco, and L. Cocolin. 2013. Aerobic deterioration stimulates outgrowth of spore-forming Paenibacillus in corn silage stored under oxygen-barrier or polyethylene films. J. Dairy Sci. 96:5206-5216.

Brashears, M. M., and M. L. Galyean. 2002. Testing of probiotic bacteria for the elimination of Escherichia coli O157:H7 in cattle. Am. Meat Inst. Found. Accessed Apr. 24, 2007. http://www.amif.org/ PRProbiotics042302.htm.

Buehner, K. P., S. Anand, G. D. Djira, and A. Garcia. 2014. Corrigendum to prevalence of thermoduric bacteria and spores on 10 Midwest dairy farms. J. Dairy Sci. 97:8009-8016.

Byrne, C. M., P. O. Kiely, D. J. Bolton, J. J. Sheridan, D. A. McDowell, and I. S. Blair. 2002. Fate of Escherichia coli O157:H7 during silage fermentation. J. Food Prot. 65:1854-1860.

Callaway, T. R., T. S. Edrington, A. D. Brabban, J. E. Keen, R. C. Anderson, M. L. Rossman, M. J. Engler, K. J. Genovese, B. L. Gwartney, J. O. Reagan, T. L. Poole, R. B. Harvey, E. M. Kutter, and D. J. Nisbet. 2006. Fecal prevalence of Escherichia coli O157, Salmonella, Listeria, and bacteriophage infecting E. coli $\mathrm{O} 157: \mathrm{H} 7$ in feedlot cattle in the southern plains region of the United States. Foodborne Pathog. Dis. 3:234-244.

Callaway, T. R., J. E. Keen, T. S. Edrington, L. H. Baumgard, L. Spicer, E. S. Fonda, K. E. Griswold, T. R. Overton, M. E. VanAmburgh, R. C. Anderson, K. J. Genovese, T. L. Poole, R. B. Harvey, and D. J. Nisbet. 2005. Fecal prevalence and diversity of Salmonella species in lactating dairy cattle in four states. J. Dairy Sci. 88:3603-3608

Carrique-Mas, J. J., S. Bedford, and R. H. Davies. 2007. Organic acid and formaldehyde treatment of animal feeds to control Salmonella: Efficacy and masking during culture. J. Appl. Microbiol. 103:88-96.

Chapman, P. A., C. A. Siddons, A. T. Cerdan Malo, and M. A. Harkin. 1997. A 1-year study of Escherichia coli O157 in cattle, sheep, pigs and poultry. Epidemiol. Infect. 119:245-250.

Chen, Y., S. Sela, M. Gamburg, R. Pinto, and Z. G. Weinberg. 2005. Fate of Escherichia coli during ensiling of wheat and corn. Appl. Environ. Microbiol. 71:5163-5170.

Christiansson, A., J. Bertilsson, and B. Svensson. 1999. Bacillus cereus spores in raw milk: Factors affecting the contamination of milk during the grazing period. J. Dairy Sci. 82:305-314.

Cocolin, L., N. Innocente, M. Biasutti, and G. Comi. 2004. The late blowing in cheese: a new molecular approach based on PCR and DGGE to study the microbial ecology of the alteration process. Int. J. Food Microbiol. 90:83-91.

Custódio, L., G. Morais, J. L. Daniel, T. Pauly, and L. G. Nussio. 2016. Effects of chemical and microbial additives on Clostridium development in sugarcane (Saccharum officinarum L.) ensiled with lime. Grassl. Sci. 62:135-143.

Dain, J. A., A. L. Neal, and R. W. Dougherty. 1955. The occurrence of histamine and tyramine in rumen ingesta of experimentally overfed sheep. J. Anim. Sci. 14:930-935.

Davies, D. R., R. J. Merry, and E. L. Bakewell. 1996. The effect of timing of slurry application on the microflora of grass and changes occurring during silage fermentation. Grass Forage Sci. 51:42-51.

Davison, H. C., A. R. Sayers, R. P. Smith, S. J. Pascoe, R. H. Davies, J. P. Weaver, and S. J. Evans. 2006. Risk factors associated with the Salmonella status of dairy farms in England and Wales. Vet. Rec. 159:871-880.

Diaz, D. E., W. M. Hagler, J. T. Blackwelder, J. A. Eve, B. A. Hopkins, K. L. Anderson, F. T. Jones, and L. W. Whitlow. 2004. Aflatoxin binders II: Reduction of aflatoxin M1 in milk by sequestering agents of cows consuming aflatoxin in feed. Mycopathologia 157:233-241.

Donald, A. S., D. R. Fenlon, and B. Seddon. 1995. The relationship between ecophysiology, indigenous microflora and growth of Listeria monocytogenes in grass silage. J. Appl. Bacteriol. 79:141-148.

Driehuis, F. 2013. Silage and the safety and quality of dairy foods: A review. Agric. Food Sci. 22:16-34.
Driehuis, F., and S. Elferink. 2000. The impact of the quality of silage on animal health and food safety: A review. Vet. Q. 22:212-216.

Driehuis, F., S. J. W. H. Oude Elferink, and S. F. Spoelstra. 1999. Anaerobic lactic acid degradation during ensilage of whole crop maize inoculated with Lactobacillus buchneri inhibits yeast growth and improves aerobic stability. J. Appl. Microbiol. 87:583-594.

Driehuis, F., J. M. Wilkinson, Y. Jiang, I. Ogunade, and A. T. Adesogan. 2018. Silage review: Animal and human health risks from silage. J. Dairy Sci. 101:4093-4110. https://doi.org/10.3168/10 .316/jds.2017-13836

Duniere, L., A. Gleizal, F. Chaucheyras-Durand, I. Chevallier, and D. Thevenot-Sergentet. 2011. Fate of Escherichia coli O26 in corn silage experimentally contaminated at ensiling, at opening or after aerobic exposure and protective effect of various bacterial inoculants. Appl. Environ. Microbiol. 77:8696-8704.

Elam, N. A., J. F. Gleghorn, J. D. Rivera, M. L. Galyean, P. J. Defoor, M. M. Brashears, and S. M. Younts-Dahl. 2003. Effects of live cultures of Lactobacillus acidophilus (strains NP45 and NP51) and Propionibacterium freudenreichii on performance, carcass, intestinal characteristics, and Escherichia coli strain O157 shedding of finishing beef steers. J. Anim. Sci. 81:2686-2698.

Farrokh,, C., K. Jordan, F. Auvray, K. Glass, H. Oppegaard, S. Raynaud, D. Thevenot, R. Condron, K. De Reu, A. Govaris, K. Heggum, M. Heyndrickx, J. Hummerjohann, D. Lindsay, S. Miszczycha, S. Moussiegt, K. Verstraete, and O. Cerf. 2013. Review of Shiga-toxin-producing Escherichia coli (STEC) and their significance in dairy production. Int. J. Food Microbiol. 162:190-212.

Field, D., M. Begley, P. M. O'Connor, K. M. Daly, F. Hugenholtz, P. D. Cotter, C. Hill, and R. P. Ross. 2012. Bioengineered nisin A derivatives with enhanced activity against both Gram-positive and Gram-negative pathogens. PLoS One 7:e46884. https://doi.org/10 .1371/journal.pone.0046884

Fusi, E., L. Rossi, R. Rebucci, F. Cheli, A. Di Giancamillo, C Domeneghini, L. Pinotti, V. Dell'Orto, and A. Baldi. 2004. Administration of biogenic amines to Saanen kids: Effects on growth performance, meat quality and gut histology. Small Rumin. Res. $53: 1-7$.

Gollop, N., V. Zakin, and Z. G. Weinberg. 2005. Antibacterial activity of lactic acid bacteria included in inoculants for silage and in silages treated with these inoculants. J. Appl. Microbiol. 98:662-666.

Griffiths, M. W. 1989. Listeria monocytogenes: Its importance in dairy industry. J. Sci. Food Agric. 47:133-158.

Guerra, N. P., and L. Pastrana. 2002. Modelling the influence of $\mathrm{pH}$ on the kinetics of both nisin and pediocin production and characterization of their functional properties. Process Biochem. $37: 10051015$.

Guerra, N. P., M. L. Rua, and L. Pastrana. 2001. Nutritional factors affecting the production of two bacteriocins from lactic acid bacteria on whey. Int. J. Food Microbiol. 70:267-281.

Hanson, D. L., G. H. Loneragan, T. R. Brown, D. J. Nisbet, M. E. Hume, and T. S. Edrington. 2016. Evidence supporting vertical transmission of Salmonella in dairy cattle. Epidemiol. Infect. 144:962-967.

Hengeveld, A. G. 1983. Sporen van boterzuurbacteriën in kuilvoer Rep. 88. Proefstation voor de Runveehouderij, schapenhouderij en paardenhouderij, Lelystad, the Netherlands.

Heron, S. J. E., J. F. Wilkinson, and C. M. Duffus. 1993. Enterobacteria associated with grass and silages. J. Appl. Bacteriol. 75:13-17.

Ho, A. J., R. Ivanekb, Y. T. Gröhnb, K. K. Nightingalea, and M. Wiedmanna. 2007a. Listeria monocytogenes fecal shedding in dairy cattle shows high levels of day today variation and includes outbreaks and sporadic cases of shedding of specific L. monocytogenes subtypes. Prev. Vet. Med. 80:287-305

Ho, A. J., V. R. Lappi, and M. Wiedmann. 2007b. Longitudinal monitoring of Listeria monocytogenes contamination patterns in a farmstead dairy processing facility. J. Dairy Sci. 90:2517-2524.

Hussein, H., and T. Sakuma. 2005. Prevalence of Shiga toxin-producing Escherichia coli in dairy cattle and their products. J. Dairy Sci. 88:450-465.

Jatkauskas, J., V. Vrotniakiene, and M. T. Voss. 2015. Fermentation characteristics and microbial variables of whole crop barley ensiled 
in big bales with or without an inoculant. Page 382 in Proc. XVII International Silage Conference.

Johansson, M., E. Emmoth, A. C. Salomonsson, and A. Albihn. 2005. Potential risks when spreading anaerobic digestion residues on grass silage crops-Survival of bacteria, moulds and viruses. Grass Forage Sci. 60:175-185.

Jones, F. T. 2011. A review of practical Salmonella control measures in animal feed. J. Appl. Poult. Res. 20:102-113.

Jonsson, A., H. Lindberg, S. Sundås, P. Lingvall, and S. Lindgren. 1990. Effect of additives on quality of big-bale silage. Anim. Feed Sci. Technol. 31:139-155.

Kaiser, E., and K. Weiss. 1997. Fermentation process during the ensiling of green forage low in nitrate. 2. Fermentation process after supplementation of nitrate, nitrite, lactic-acid bacteria and formic acid. Arch. Anim. Nutr. 50:187-200.

Kaiser, E., K. Weiss, and J. Zimmer. 1997. Fermentation process during the ensiling of green forage low in nitrate-Fermentation process in untreated green forage. Archiv. Fur. Tierernahrung. 50:87-102.

Kung, L., Jr., M. R. Stokes, and C. J. Lin. 2003. Silage additives. Chapter 7. Pages 305-360 in Silage Science and Technology. D. R. Buxton, R. E. Muck, and J. J. Harrison, ed. Madison, WI. American Soc. Agron.

Kuwano, K., N. Tanaka, T. Shimizu, K. Nagatoshi, S. Nou, and K. Sonomoto. 2005. Dual antibacterial mechanisms of nisin $\mathrm{Z}$ against Gram-positive and Gram-negative bacteria. Int. J. Antimicrob. Agents 26:396-402.

Langvad, B., M. N. Skov, E. Rattenborg, J. E. Olsen, and D. L. Baggesen. 2006. Transmission routes of Salmonella typhimurium DT104 between 14 cattle and pig herds in Denmark demonstrated by molecular fingerprinting. J. Appl. Microbiol. 101:883-890.

Lättemäe, P., and P. Lingvall. 1996. Effect of hexamine and sodium nitrite in combination with sodium benzoate and sodium propionate on fermentation and storage stability of wilted and long cut grass silage. Swed. J. Agric. Res. 26:135-146.

Lema, M., L. Williams, and D. R. Rao. 2001. Reduction of fecal shedding of enterohemorrhagic Escherichia coli O157:H7 in lambs by feeding microbial feed supplement. Small Rumin. Res. 39:31-39.

Lingaas, F., and B. Tveit. 1992. Etiology of acetonemia in Norwegian cattle. 2. Effect of butyric acid, valeric acid, and putrescine. J. Dairy Sci. 75:2433-2439.

Lueger, A., T. C. Schroeder, and D. G. Renter. 2012. Feedlot costs of vaccinating cattle for E. coli. K-State Department of Agricultural Economics. Accessed Dec. 3, 2016. http://www.agmanager .info/livestock/budgets/production/beef/TCS_FactSheet _EcoliVaccination_12-07-12.pdf.

Lynn, T. V., D. D. Hancock, T. E. Besser, J. H. Harrison, D. H. Rice, N. T. Stewart, and L. L. Rowan. 1998. The occurrence and replication of Escherichia coli in cattle feeds. J. Dairy Sci. 81:1102-1108.

Madigan, M. T., J. M. Martinko, P. V. Dunlap, and D. P. Clark. 2009. Biology of Microorganisms. 12th ed. Pearson Benjamin Cummings, San Francisco, CA.

Magnusson, M., A. Christiansson, and B. Svensson. 2007. Bacillus cereus spore during housing of dairy cows: Factors affecting contamination of raw milk. J. Dairy Sci. 90:2745-2754.

Mantovani, H. C., and J. B. Russell. 2003. Inhibition of Listeria monocytogenes by bovicin HC5, a bacteriocin produced by Streptococcus bovis HC5. Int. J. Food Microbiol. 89:77-83.

Masiello, S. N., N. H. Martin, R. D. Watters, D. M. Galton, Y. H. Schukken, M. Wiedmann, and K. J. Boor. 2014. Identification of dairy farm management practices associated with the presence of psychrotolerant sporeformers in bulk tank milk. J. Dairy Sci. 97:4083-4096.

McDonald, P., N. Henderson, and S. Heron. 1991. The Biochemistry of Silage. 2nd ed. Chalcombe Publications, Bucks, UK.

McDonald, P., and R. Whittenbury. 1973. Page 33 In Chemistry and Biochemistry of Herbage, vol. 3. G. W. Butler and R. W. Bailey, ed. Academic Press, New York, NY.

McGuirk, S. M. 2008. Disease management of dairy calves and heifers. Vet. Clin. North Am. Food Anim. Pract. 24:139-153.
Mead, P. S., L. Slutsker, V. Dietz, L. F. McCaig, J. S. Bresee, C. Shapiro, P. M. Griffin, and R. V. Tauxe. 1999. Food-related illness and death in the United States. Emerg. Infect. Dis. 5:607-625.

Mechie, S. C., P. A. Chapman, and C. A. Siddons. 1997. A fifteenmonth study of Escherichia coli O157:H7 in a dairy herd. Epidemiol. Infect. 118(Suppl. 1):17-25.

Myllykoski,, J., M. Lindsrom, R. Keto-Timonen, H. Soderholm, H. Kallis, A. Sukura, and H. Korkeala. 2009. Type C bovine botulism outbreak due to carcass contaminated non-acidified silage. Epidemiol. Infect. 137:284-293.

Moran, J. P., D. Pullar, and T. R. Owen. 1993. The development of a novel bacterial inoculant to reduce mould spoilage and improve the silage fermentation in big bale silage. P. O'Kiely, M. O'Connell, and J. Murphy, ed. Silage research 1993. Pages 85-86 in Proc. Int. Conf. Silage Res., 10th. Dublin, Ireland. Dublin City University, Dublin, Ireland.

Muck, R. E. 2010. Silage microbiology and its control through additives. Rev. Bras. Zootec. 39:182-191.

Muck, R. E., L. E. Moser, and R. E. Pitt. 2003. Postharvest factors affecting ensiling. Chapter 6. Pages 305-360 in Silage Science and Technology. D. R. Buxton, R. E. Muck, and J. J. Harrison, ed. Am. Soc. Of Agron., Madison, WI.

Muck, R. E., E. M. G. Nadeau, T. A. McAllister, F. E. ContrerasGovea, M. C. Santos, and L. Kung Jr. 2018. Silage review: Recent advances and future uses of silage additives. J. Dairy Sci. 101:3980-4000. https://doi.org/10.3168/jds.2017-13839.

Nielsen, L. R., L. D. Warnick, and M. Greiner. 2007. Risk factors for changing test classification in the Danish surveillance program for Salmonella in dairy herds. J. Dairy Sci. 90:2815-2825.

Nightingale, K. K., E. D. Fortes, A. J. Ho, Y. H. Schukken, Y. T. Grohn, and M. Wiedmann. 2005. Evaluation of farm management practices as risk factors for clinical listeriosis and fecal shedding of Listeria monocytogenes in ruminants. JAVMA 227:1808-1814.

Nightingale, K. K., Y. H. Schukken, C. R. Nightingale, E. D. Fortes, A. J. Ho, Z. Her, Y. T. Grohn, P. L. McDonough, and M. Wiedmann. 2004. Ecology and transmission of Listeria monocytogenes infecting ruminants and in the farm environment. Appl. Environ. Microbiol. 70:4458-4467.

Nishino, N., H. Hattori, H. Wada, and E. Touno. 2007. Biogenic amine production in grass, maize and total mixed ration silages inoculated with Lactobacillus casei or Lactobacillus buchneri. J. Appl. Microbiol. 103:325-332.

Nucera, D. M., M. A. Grassi, P. Morra, S. Piano, E. Tabacco, and G. Borreani. 2016. Detection, identification, and typing of Listeria species from baled silages fed to dairy cows. J. Dairy Sci. 99:6121-6133.

Ogunade, I. M., Y. Jiang, D. H. Kim, A. A. Pech Cervantes, K. G. Arriola, D. Vyas, Z. G. Weinberg, K. C. Jeong, and A. T. Adesogan. 2017. Fate of Escherichia coli O157:H7 and bacterial diversity in corn silage contaminated with the pathogen and treated with chemical or microbial additives. J. Dairy Sci. 100:1780-1794.

Ogunade, I. M., D. H. Kim, Y. Jiang, Z. G. Weinberg, K. C. Jeong, and A. T. Adesogan. 2016. Control of Escherichia coli O157:H7 in contaminated alfalfa silage: Effects of silage additives. J. Dairy Sci. 99:4427-4436.

Pahlow, G., R. E. Muck, F. Driehuis, S. J. W. H. Oude Elferink, and S. F. Spoelstra. 2003. Microbiology of ensiling. Chapter 2. Pages 31-93 in Silage Science and Technology. D. R. Buxton, R. E. Muck, and J. H. Harrison, ed. American Society of Agronomy, Madison, WI.

Pauly, T. M., and W. A. Tham. 2003. Survival of Listeria monocytogenes in wilted and additive-treated grass silage. Acta Vet. Scand. 44:73-86.

Pedroso, A. F., A. T. Adesogan, O. C. M. Queiroz, and S. Williams. 2010. Control of Escherichia coli O157:H7 in corn silage with or without various inoculants: Efficacy and mode of action. J. Dairy Sci. 93:1098-1104.

Peterson, R. E., T. J. Klopfenstein, G. E. Erickson, J. Folmer, S. Hinkley, R. A. Moxley, and D. R. Smith. 2007. Effect of Lactobacillus acidophilus strain NP51 on Escherichia coli O157:H7 fecal 
shedding and finishing performance in beef feedlot cattle. J. Food Prot. 70:287-291.

Phuntsok, T., M. A. Froetschel, H. E. Amos, M. Zheng, and Y. W. Huang. 1998. Biogenic amines in silage, apparent post-ruminal passage, and the relationship between biogenic amines and digestive function and intake by steers. J. Dairy Sci. 81:2193-2203.

Queiroz, O. C., S. C. Kim, and A. T. Adesogan. 2012. Effect of treatment with a mixture of bacteria and fibrolytic enzymes on the quality and safety of corn silage infested with different levels of rust. J. Dairy Sci. 95:5285-5291.

Reinstein, S., J. T. Fox, X. Shi, and T. G. Nagaraja. 2007. Prevalence of Escherichia coli O157:H7 in gallbladders of beef cattle. Appl. Environ. Microbiol. 73:1002-1004.

Rings, D. M. 2004. Clostridial disease associated with neurological signs: Tetanus, botulism, and enterotoxemia. Vet. Clin. North Am. Food Anim. Pract. 20:379-391.

Russell, J. B., F. Diez-Gonzalez, and G. N. Jarvis. 2000. Potential effects of cattle diets on the transmission of pathogenic Escherichia coli to humans. Microbes Infect. 2:45-53.

Ryser, E. T., and E. H. Marth. 2007. Listeria, Listeriosis and Food Safety. 3rd ed. CRC Press, Taylor \& Francis group, Boca Raton, FL.

Scallan, E., R. M. Hoekstra, F. J. Angulo, R. V. Tauxe, M. Widdowson, S. L. Roy, J. L. Jones, and P. M. Griffin. 2011. Foodborne Illness acquired in the United States-Major pathogens. Emerg. Infect. Dis. 17:7-15.

Schukken, Y. H., Y. T. Grohn, and M. Wiedmann. 2003. Epidemiology of listeriosis. Pages 221-232 in Microbial Food Safety in Animal Agriculture. M. E. Torrence and R. E. Isaacson, ed. Iowa State, Ames.

Soni, A., I. Oey, P. Silcock, and P. Bremer. 2016. Bacillus spores in the food industry: A review on resistance and response to novel inactivation technologies. Compr. Rev. Food Sci. Food Saf. 15:1139 1148.

Sparo, M. D., M. S. Castro, P. J. Andino, M. V. Lavigne, C. Ceriani, G. L. Gutiérrez, M. M. Fernández, M. C. De Marzi, E. L. Malchiodi, and M. A. Manghi. 2006. Partial characterization of enterocin MR99 from a corn silage isolate of Enterococcus faecalis. J. Appl. Microbiol. 100:123-134.

Spoelstra, S. F. 1985. Nitrate in silage. A review. Grass Forage Sci. 40:1-11.

Stephan, R., and K. Kuhn. 1999. Prevalence of verotoxin-producing Escherichia coli (VTEC) in bovine coli mastitis and their antibiotic resistance patterns. Zentralbl. Veterinarmed. B. 46:423-427.

te Giffel, M. C., A. Wagendorp, A. Herrewegh, and F. Driehuis. 2002. Bacterial spores in silage and raw milk. Antonie van Leeuwenhoek $81: 625-630$.

Thomas, L. V., J. W. T. Wimpenny, and J. G. Davis. 1993. Effect of three preservatives on the growth of Bacillus cereus, Vero-cytotoxigenic, Escherichia coli and Staphylococcus aureus on plates with gradients of $\mathrm{pH}$ and sodium chloride concentration. Int. J. Food Microbiol. 17:289-301.

USDA-APHIS. 2001. Escherichia coli O157 in United States feedlots. Center for Epidemiology and Animal Health, Fort Collins, CO.

Van Kessel, J. S., J. S. Karns, L. Gorski, B. J. McCluskey, and M. L. Perdue. 2004. Prevalence of Salmonella, Listeria monocytogenes, and fecal coliforms in bulk tank milk on US dairies. J. Dairy Sci $87: 2822-2830$.

Van Os, M., B. Lassalas, S. Toillon, and J. P. Jouany. 1995. In vitro degradation of amines by rumen microorganisms. J. Agric. Sci. Camb. 125:299-305.

van Schooten, H. A., J. Corporaal, and S. F. Spoelstra. 1989. Effect van verschillende oogstmachines en melasse op de kwaliteit van slecht voorgedroogd kuilvoer. Rep. 118. Proefstation voor de Rundveehouderij, schapenhouderij en paardenhouderij, Lelystad, the Netherlands.

Vilar, M. J., E. Yus, M. L. Sanjuan, F. J. Diequez, and J. L. Rodriquez-Otero. 2007. Prevalence of and risk factors for Listeria species on dairy farms. J. Dairy Sci. 90:5083-5088.

Vissers, M. M. M., F. Driehuis, M. C. Te Giffel, P. De Jong, and J. M. G. Lankveld. 2007a. Concentration of butyric acid bacteria spores in silage and relationships with aerobic deterioration. J. Dairy Sci. 90:928-936.

Vissers, M. M. M., F. Driehuis, M. C. Te Giffel, P. De Jong, and J. M. G. Lankveld. 2007b. Quantification of the transmission of microorganisms to milk via dirt attached to the exterior of teats. J. Dairy Sci. 90:3579-3582.

Weinberg, Z. G., G. Ashbell, Y. Chen, M. Gamburg, and S. Sela. 2004. The effect of sewage irrigation on safety and hygiene of forage crops and silage. Anim. Feed Sci. Technol. 116:271-280.

Weissbach, F., and H. Honig. 1996. Uber die Vorhersage und Steuerung des Gärungsverlaufs bei der Silierung von Grünfutter aus extensivem Anbau. Landbauforsch. Völkenrode 1:10-17.

Wesley, I. V. 2007. Listeriosis in Animals. Pages 55-84 in Listeria, Listeriosis and Food Safety. 3th ed. E. T. Ryser and E. H. Marth, ed. CRC Press, New York, NY.

Whitlow, L. W., and W. M. Hagler. 2009. Mycotoxin contamination of feedstuffs-An additional stress factor for dairy cattle. Accessed Oct. 15, 2017. www.cals.ncsu.edu/an_sci/extension/dairy/ mycoto 1 .pdf.

Wiedmann, M. 2003. An integrated science based approach to dairy food safety: Listeria monocytogenes as a model system. J. Dairy Sci. 86:1865-1875.

Wilkinson, J. M. 1999. Silage and health. Pages 67-81 in Silage production in relation to animal performance, animal health, meat and milk quality. Proceedings of the 12th International Silage Conference, July 5-7, Uppsala, Sweden. T. Pauly, ed. Swedish University of Agricultural Sciences, Uppsala, Sweden.

Wilson, A. R., D. Sigee, and H. A. S. Epton. 2005. Anti-bacterial activity of Lactobacillus plantarum strain SK1 against Listeria monocytogenes is due to lactic acid production. J. Appl. Microbiol. 99:1516-1522.

Woolford, M. K. 1975. Microbiological screening of straight-chain fatty acids $(\mathrm{C} 1-\mathrm{C} 12)$ as potential silage additives. J. Sci. Food Agric. 26:219-228.

Yang, S. C., C. H. Lin, C. T. Sung, and J. Y. Fang. 2014. Antibacterial activities of bacteriocins: Application in food and pharmaceuticals. Front. Microbiol. 5:241.

Yildirim, Y. K., M. Avsar, and M. Yıldırım. 2002. Factors affecting the adsorption of buchnericin LB, a bacteriocin produced by Lactocobacillus buchneri. Microbiol. Res. 157:103-107. 